\title{
Fashion awareness and peer pressure among adolescents
}

\author{
SRISHTI MAURYA AND SHRUTI SHARMA
}

Received: 17.08.2013; Revised: 11.09.2014; Accepted: 23.09.2014

See end of the paper for authors' affiliations

\section{SRISHTI MAURYA}

Departments of Textiles and

Apparel Designing, Sam

Higginbottom Institute of Agriculture, Technology and

Sciences, ALLAHABAD (U.P.)

INDIA

Email:srishti.maurya@gmail.com
ABSTRACT : In seeking to expand our understanding of fashion, present study examines the relationship between personal characteristics. The result clearly indicated that female respondents were perceived to be more fashion conscious than males and also females shopped more often than males. The awareness of fashion trends and brand conscious was also high among female whereas male are more affected by peer pressure. But common governing factor among all the respondents was the economic status of the families corresponding to their family size. The study thus indicated that the correlation between adolescents, fashion, brand, and peer pressure was found to be affective in Indian scenario as well.

KEY WORDS: Adolescent, Consciousness, Fashion trend

— HOW TO CITE THIS PAPER : Maurya, Srishti and Sharma, Shruti (2014). Fashion awareness and peer pressure among adolescents. Asian J. Home Sci., 9 (2) : 375-379. 